\title{
Characterisation of a recombinant $\beta$-xylosidase (xylA) from Aspergillus oryzae expressed in Pichia pastoris
}

\author{
Narin Kirikyali, Jonathan Wood and Ian F Connerton ${ }^{*}$
}

\begin{abstract}
$\beta$-xylosidases catalyse the hydrolysis of short chain xylooligosaccharides from their non-reducing ends into xylose. In this study we report the heterologous expression of Aspergillus oryzae $\beta$-xylosidase (Xy|A) in Pichia pastoris under the control of the glyceraldehyde-3-phosphate dehydrogenase promoter. The recombinant enzyme was optimally active at $55^{\circ} \mathrm{C}$ and $\mathrm{pH} 4.5$ with $\mathrm{K}_{\mathrm{m}}$ and $V_{\max }$ values of $1.0 \mathrm{mM}$ and $250 \mu \mathrm{mol} \mathrm{min}{ }^{-1} \mathrm{mg}^{-1}$ respectively against 4-nitrophenyl $\beta$-xylopyranoside. Xylose was a competitive inhibitor with a $K_{i}$ of $2.72 \mathrm{mM}$, whereas fructose was an uncompetitive inhibitor reducing substrate binding affinity $\left(K_{m}\right)$ and conversion efficiency $\left(V_{\text {max }}\right)$. The enzyme was characterised to be an exo-cutting enzyme releasing xylose from the non-reducing ends of $\beta-1,4$ linked xylooligosaccharides $\left(X_{2}, X_{3}\right.$ and $\left.X_{4}\right)$. Catalytic conversion of $X_{2}, X_{3}$ and $X_{4}$ decreased $\left(V_{\max }\right.$ and $\left.k_{c a t}\right)$ with increasing chain length.
\end{abstract}

Keywords: Aspergillus oryzae; Xylose; $\beta$-xylosidase; Enzyme kinetics; Protein expression

\section{Introduction}

Xylanolytic and cellulolytic enzymes encoded by filamentous fungi have been employed in several industrial applications for improving digestibility in animal feed, production of sweeteners, pharmaceuticals, additive chemicals for biofuel production and for the replacement of hazardous chemicals in textile and paper manufacture (Michelin et al. 2012). As a consequence it has been a necessity for enzymes involved in cellulose and hemicellulose hydrolysis to be individually identified and characterised in order to utilise them in the process of converting waste agricultural materials into valuable products with greater efficiency.

Hemicellulose is comprised of a linear main chain $\beta-1,4$ linked D-xylose backbone with short lateral side chains of different lower molecular weight sugar residues (Dyk and Pletschke 2012). Enzymatic hydrolysis of hemicellulose commences with the removal of side chains that block the sites where xylanases cleave the xylan backbone. Endo-1, $4-\beta$-xylanase enzymes cleave the glycosidic bonds in a selective manner depending on the chain length, degree of branching of substrate molecules and the presence of

\footnotetext{
* Correspondence: ian.connerton@nottingham.ac.uk

Division of Food Sciences, School of Biosciences, University of Nottingham, Sutton Bonington Campus, Loughborough LE12 5RD, UK
}

alternative carbohydrate moieties (Polizeli et al. 2005). Cleavage of the xylan backbone yields xylooligosaccharides and the final trimming is carried out by $\beta$-xylosidase, whereby short chain oligosaccharides and xylobiose are hydrolysed from the non-reducing termini to release $x y-$ lose monomers (Polizeli et al. 2005; Teng et al. 2011).

Among xylanolytic enzymes, endo-xylanases and $\beta$ xylosidases have attracted attention as they commence and complete the breakdown of hemicellulose fraction respectively (Kulkarni et al. 1999). For comprehensive hydrolysis $\beta$-xylosidases play an important role in the removal of xylooligosaccharides from the catalytic environment, which assists by the elimination of the end-product inhibitors of endo-xylanases.

The gene encoding for XylA was previously identified by Kitamoto et al. (1999) and was reported to be responsible for the rapid browning of soy sauce. In addition Kitamoto et al. (1999) were interested in the antisense inhibition of XylA expression in order to hinder the translation in Aspergillus oryzae KBN616 to produce a mutant strain that could be used in Japanese food industry. However, XylA is a potentially efficient candidate for the facilitation of hydrolysis of hemicellulose applications in industrial processes. The work presented here reports the expression 
of a $\beta$-xylosidase from Aspergillus oryzae in Pichia pastoris and the kinetic characterisation of the recombinant enzyme.

\section{Materials and methods Construction of expression vector}

The $\beta$-xylosidase encoding gene $(x y l A)$ was kindly provided by Noriyuki Kitamoto (Aichi Industrial Technology Institute, Japan). The gene sequence appears in the DDBJ, EMBL, and GenBank nucleotide sequence databases under accession number AB013851. The gene was sub-cloned into $\mathrm{pCR}^{\circ} 2.1$ and subsequently into the Pichia pastoris expression vector pPpHis4_GAP_BglII (TU Graz) under control of the glyceraldehyde-3-phosphate dehydrogenase (GAP) promoter.

\section{Transformation and expression of recombinant $\beta$-xylosidase in Pichia pastoris}

Plasmid DNA $(10 \mu \mathrm{g})$ containing the xylA gene sequence was linearized with BglII for integration at the GAP locus and was transformed into P. pastoris GS115 using Invitrogen Pichia Easycomp kit (as per manufacturers' guidelines). Positive transformants, displaying the $\mathrm{His}^{+}$phenotype on Regeneration Dextrose medium (RD) agar plates (1 M sorbitol, $2 \%$ dextrose, $1.34 \%$ yeast nitrogen base, $4 \times 10^{-5} \%$ biotin, $0.005 \%$ amino acids (L-glutamic acid, L-methionine, L-lysine, L-leucine, L-isoleucine) and 1.5\% agar), before transfer onto RD plates containing $50 \mu \mathrm{g} \mathrm{ml}^{-1}$ bromo-4chloro-3-indolyl $\beta$-D-xylopyranoside (X-xyl) (SigmaAldrich, UK) and incubated at $30^{\circ} \mathrm{C}$ for 2 days. Functional expression of the $\beta$-xylosidase under the control of GAP promoter was tested by cleavage of xylopyranoside from the synthetic indicator X-xyl.

A single colony displaying the highest level of blue precipitate was sub-cultured from the RD plate onto a YPD plate (1\% yeast extract, $2 \%$ peptone, $2 \%$ glucose, $2 \%$ agar) and incubated at $30^{\circ} \mathrm{C}$ for 3 days. A seed culture was raised using a single colony inoculated into $50 \mathrm{ml}$ YPD liquid medium, incubated at $28^{\circ} \mathrm{C}$ overnight. One hundred millilitres of YPD broth was then inoculated to $1 \mathrm{OD}_{600 \mathrm{~nm}}$ and incubated for $72 \mathrm{~h}$ at $28^{\circ} \mathrm{C}$. One $\mathrm{ml}$ of culture was removed every $24 \mathrm{~h}$ to test expression levels using the synthetic 4-nitrophenyl $\beta$-xylopyranoside (PNPX) as described in section 2.4. Following incubation the cells were harvested by centrifugation at $4000 \times \mathrm{g}$ for $10 \mathrm{~min}$.

\section{Purification of recombinant $\beta$-xylosidase}

Following centrifugation the culture supernatant was concentrated using a Sartorius Sartocon Slice then diafiltered with 10 volumes of Tris-salt buffer $(10 \mathrm{mM}$ Tris, $50 \mathrm{mM} \mathrm{NaCl}, \mathrm{pH} 7.5)$. The concentrate was then stabilised using $30 \%(\mathrm{w} / \mathrm{v})$ sucrose based on protein concentration and frozen for long term storage at $-20^{\circ} \mathrm{C}$. Prior to enzymatic assays the $30 \%(\mathrm{w} / \mathrm{v})$ sucrose was removed from the recombinant enzyme concentrates using a Vivaspin concentrator (GE Healthcare, UK) with a $10 \mathrm{kDa}$ molecular weight cut off membrane filter and the filtrate was washed with Tris-salt buffer $(10 \mathrm{mM}$ Tris, $50 \mathrm{mM} \mathrm{NaCl}, \mathrm{pH} 7.5)$.

\section{Enzyme assays using synthetic substrates}

Assays for $\beta$-xylosidase activity were performed by measuring the pNP released from p-nitrophenyl glycoside synthetic substrates 4-nitrophenyl- $\beta$-D-xylopyranoside (PNPX), 4-nitrophenyl- $\beta$-D-glucopyranoside (PNPG) and 4-nitrophenyl- $\alpha$-L-arabinofuranoside (PNPAf) in a final volume of $4 \mathrm{ml}$ for $20 \mathrm{~min}$ in $50 \mathrm{mM}$ sodium phosphate buffer $\mathrm{pH} 6.0$ at $50^{\circ} \mathrm{C}$. Reactions were terminated by the addition of $1 \mathrm{M} \mathrm{Na}_{2} \mathrm{CO}_{3}$ and the amount of released pNP was measured at $\mathrm{OD}_{410 \mathrm{~nm}}$. One unit (U) of $\beta$-xylosidase activity is defined as the amount of enzyme required to release $1 \mu \mathrm{mol}$ of $\mathrm{pNP}$ per min under assay conditions. Kinetic parameters $\left(\mathrm{K}_{\mathrm{m}}\right.$ and $\left.\mathrm{V}_{\max }\right)$ were determined by the measurement of activity against pNPX using different substrate concentrations (0.5 - $12 \mathrm{mM})$ using the standard assay procedure. Enzyme assays were performed in triplicate and are presented as mean values with standard error.

\section{Enzyme assays using xylooligosaccharides}

Activities against xylobiose, xylotriose and xylotetraose were determined at varying substrate concentrations $\left(0.25-4 \mathrm{mg} \mathrm{ml}^{-1}\right)$ in a final volume of $1 \mathrm{ml}$ for $10 \mathrm{~min}$ in $50 \mathrm{mM}$ sodium phosphate buffer $\mathrm{pH} 6.0$ at $50^{\circ} \mathrm{C}$. All assays were carried out in triplicate and were terminated by the addition of $1 \mathrm{M} \mathrm{Na}_{2} \mathrm{CO}_{3}$. Reaction products were separated according to molecular size by HPLC (Dionex ICS-3000 SP) with CarboPacTM PA20 column $(3 \times$ $150 \mathrm{~mm}$ ) and a gradient of $10-50 \mathrm{mM}$ sodium hydroxide was applied for $20 \mathrm{~min}$ at a flow rate of $1 \mathrm{ml} \mathrm{min}^{-1}$. The products were quantified on the basis of standard peak areas from various concentrations of control xylose, xylobiose, xylotriose and xylotetraose solutions. Enzyme assays were performed in triplicate and are presented as mean values with standard deviations.

\section{Inhibition studies}

To investigate the effect of end product xylose on catalytic activity, reactions were carried out in the presence of various xylose concentrations from $1 \mathrm{mM}$ to $80 \mathrm{mM}$ using synthetic substrate concentrations of either $1 \mathrm{mM}$ or $4 \mathrm{mM}$ pNPX. To further confirm the type of inhibition, kinetic constants were determined from experiments carried out using fixed inhibitor concentrations of $5 \mathrm{mM}$ xylose at varying substrate concentrations from $0.25 \mathrm{mM}$ to $8 \mathrm{mM}$ under standard assay conditions. 
The effects of monosaccharide sugars (20 mM glucose, mannose, galactose, arabinose, fructose and xylose), metal ions and chemicals $\left(10-20 \mathrm{mM} \mathrm{LiCl}, \mathrm{KCl}, \mathrm{ZnCl}_{2}\right.$, SDS, EDTA and DTT) on enzyme activity were tested using $50 \mathrm{mM}$ sodium phosphate buffer $\mathrm{pH} 6,1 \mathrm{mM}$ pNPX and $2 \mu \mathrm{g}$ of enzyme at $50^{\circ} \mathrm{C}$ for $10 \mathrm{~min}$ in a final volume of $4 \mathrm{ml}$ and measured optical density of released p-nitrophenyl at $\mathrm{OD}_{410 \mathrm{n}} \mathrm{m}$.

\section{Determination of protein concentration}

Protein concentrations were determined by the standard assay procedure using Pierce Coomassie ${ }^{\oplus}$ Plus Protein Assay Reagent. Sample diluents were used as the blank and the absorbance measured at $\mathrm{OD}_{595 \mathrm{~nm}}$. All assays were performed in triplicate and the $O_{595 \mathrm{~nm}}$ readings of unknown sample were compared against BSA protein standard series which covered the range of concentrations between 50 and $1500 \mu \mathrm{g} \mathrm{ml}^{-1}$.

\section{Determination of molecular mass by SDS-PAGE}

SDS-PAGE was performed using $8 \%$ polyacrylamide gels according to the method described by Laemmli (1970). Protein bands were stained with colloidal Coomassie Blue. Bands from SDS-PAGE were excised and were subjected to trypsin digestion prior to mass spectrometry analysis.

\section{Mass spectrometry}

Analyses of samples were carried out by LC-ESI-tandem MS on a Q-TOFII mass spectrometer fitted with a nanoflow ESI (electrospray ionization) source (Waters Ltd, UK). Peptides were separated on a PepMap C18 reverse phase, $75 \mu$ mi.d., 15-cm column (LC Packings) and delivered online to the MS via a CapLC HPLC system. Sequence interpretation for individual peptides was performed using the PepSeq MASCOT tool of the MassLynx ${ }^{\text {TM }} 4.0$ software package (Waters).

\section{Results}

\section{Characterisation of recombinant $\beta$-xylosidase}

The $\beta$-xylosidase gene is contained within an open reading frame of 2397 nucleotides with no introns, which encodes a protein of 798 amino acids. A putative signal peptide was identified by SignalP software, thus the mature protein was predicted to be 778 amino acids with a molecular mass of $84.7 \mathrm{kDa}$. The recombinant enzyme was recovered from Pichia pastoris culture supernatant at approximately $100 \mathrm{mg} \mathrm{L}^{-1}$. NetNGly 1.0 predicted 12 potential $\mathrm{N}$-glycosylation sites for $\beta$-xylosidase, and consistent with this, the recombinant enzyme was heterogeneous with a molecular mass estimated between 153 and $165 \mathrm{kDa}$ on SDS-PAGE (Figure 1). The recombinant protein was excised from SDS-PAGE and the masses and protein sequences of tryptic peptides were determined using mass spectrometry to confirm the protein

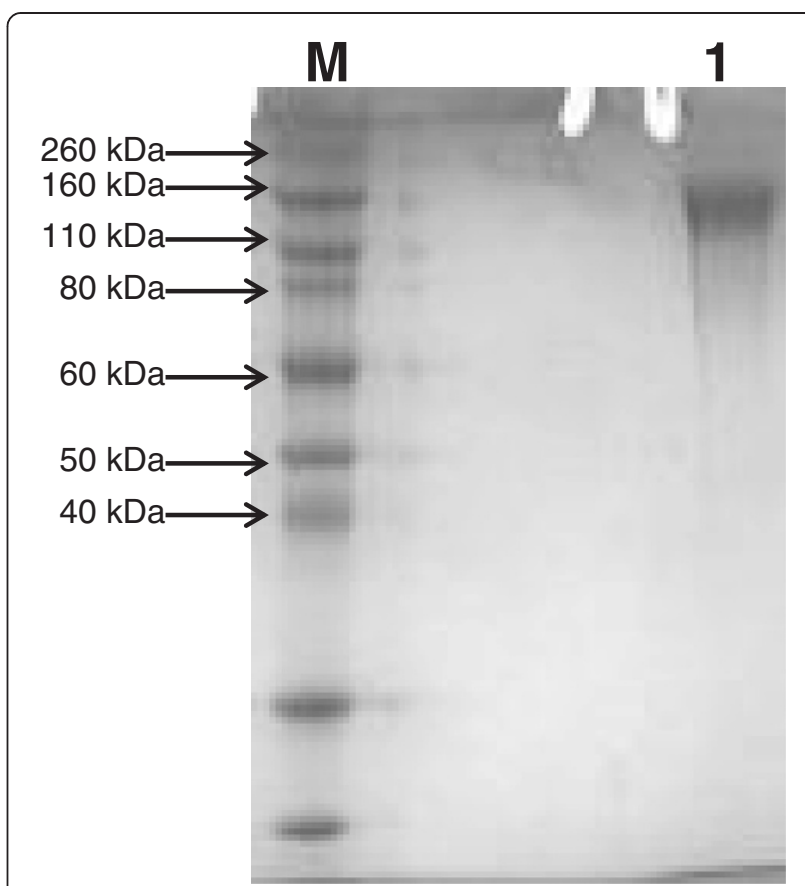

Figure 1 SDS-PAGE of recombinant $\beta$-xylosidase. Lane $M$, pre-stained Novex-Invitrogen protein marker. Lane 1, recombinant $\beta$-xylosidase.

product was exo-1,4 $\beta$-xylosidase originating from $A s$ pergillus oryzae.

\section{Determination of optimal conditions}

The optimum temperature was determined by incubation of the recombinant enzyme in the presence of $50 \mathrm{mM}$ sodium phosphate buffer $\mathrm{pH} 6.0$ and $2 \mathrm{mM}$ 4-nitrophenyl $\beta$-xylopyranoside (PNPX) for $15 \mathrm{~min}$ at varying temperatures between $20^{\circ} \mathrm{C}$ and $90^{\circ} \mathrm{C}$. The enzyme displayed optimum activity at $55^{\circ} \mathrm{C}$ and retained more than $90 \%$ catalytic activity between the ranges of $50-60^{\circ} \mathrm{C}$ (Figure 2A).

The optimum $\mathrm{pH}$ of enzymatic activity was assayed in phosphate buffer system of varying $\mathrm{pH}$ values from 2-9 in the presence of $2 \mathrm{mM}$ PNPX. The enzyme displayed activity within a narrow $\mathrm{pH}$ range, with an optimum of $\mathrm{pH} 4.5$ and at least $65 \%$ activity from $\mathrm{pH} 3-6$; less than $5 \%$ activity was observed at $\mathrm{pH} 7-9$ (Figure $2 \mathrm{~B}$ ).

\section{Substrate specificity and kinetic analysis}

The substrate specificity of the recombinant enzyme was determined using various 4-nitrophenyl glycoside synthetic substrates and xylooligosaccharides. Recombinant XylA hydrolysed 4-nitrophenyl $\beta$-xylopyranoside efficiently but had trace hydrolytic activities against 4-nitrophenyl- $\beta$-Dglucopyranoside or 4-nitrophenyl- $\alpha$-L-arabinofuranoside. Specific activities were determined as 150, 2 and $0.9 \mathrm{U} \mathrm{mg}^{-1}$ for PNPX, PNPAf, PNPG respectively. 


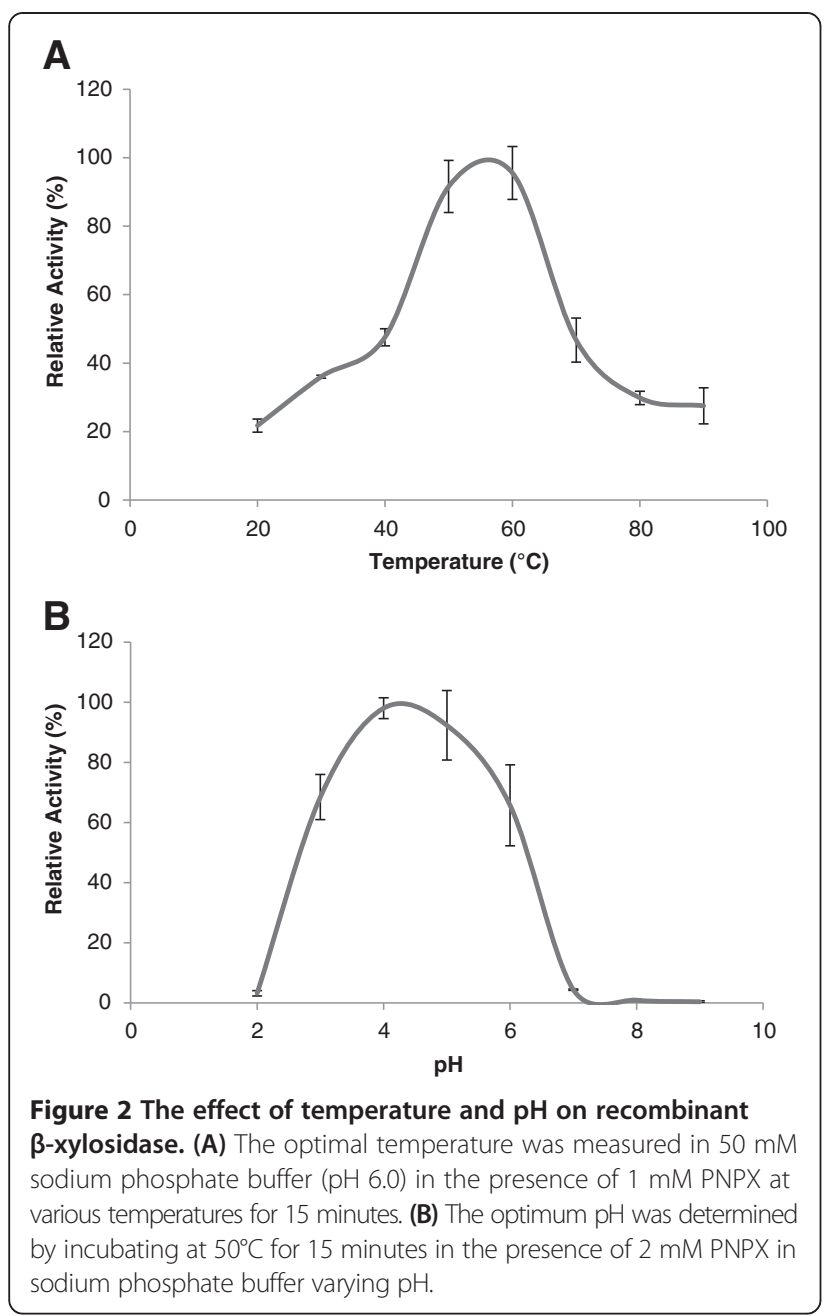

Kinetic constants for synthetic and natural substrates were determined using Hanes plots (Table 1). The enzyme exhibited $\mathrm{K}_{\mathrm{m}}$ and $\mathrm{V}_{\max }$ values of $1.0 \mathrm{mM}$ and $250 \mu \mathrm{mol} \mathrm{min} \mathrm{mg}^{-1}$ respectively for the hydrolysis of 4-nitrophenyl $\beta$-xylopyranoside. Addition of the reaction product xylose resulted in enzyme inhibition. Kinetic constants were determined using Hanes plots from experiments carried out using a fixed inhibitor concentration of $20 \mathrm{mM}$ xylose at varying PNPX concentrations (0.5 -
$4 \mathrm{mM})$. The $\mathrm{K}_{\mathrm{m}}$ was altered whilst the $\mathrm{V}_{\max }$ remained unchanged, suggesting that xylose is a competitive inhibitor. A $K_{i}$ of $2.7 \mathrm{mM}$ for xylose was determined from Dixon plots. The addition of $20 \mathrm{mM}$ fructose also had an inhibitory effect. Hanes plots indicated that the catalytic conversion of substrate into product was altered in terms of a reduction in the $V_{\max }$ and substrate affinity $\left(\mathrm{K}_{\mathrm{m}}\right)$, exhibiting the characteristics of uncompetitive inhibition.

The degradation of various xylooligosaccharides $\left(\mathrm{X}_{2}\right.$, $\mathrm{X}_{3}$ and $\mathrm{X}_{4}$ ) by recombinant XylA was analysed by HPLC. Xylose was released from all substrates and the rate of xylose released decreased with increasing chain length of the xylooligosaccharide. Table 1 shows reductions in the catalytic conversion parameters $\mathrm{V}_{\text {max }}$ and $\mathrm{k}_{\text {cat }}$ with respect to the increasing chain length of the xylooligosaccharides. The relative affinity of XylA towards the natural substrate xylotetraose $\left(\mathrm{X}_{4}\right)$ was significantly greater than xylobiose $\left(\mathrm{X}_{2}\right)$ or xylotriose $\left(\mathrm{X}_{3}\right)$ with respect to the $\mathrm{K}_{\mathrm{m}}$ values.

\section{Effect of carbohydrates on catalytic activity}

The catalytic activity of recombinant $\beta$-xylosidase was measured using $1 \mathrm{mM}$ pNPX as substrate in the presence of $20 \mathrm{mM}$ sugar solutions to test whether the enzyme was inhibited or enhanced (Figure 3A). In the presence of $20 \mathrm{mM}$ xylose and fructose the catalytic activity was reduced to $18 \%$ and $26 \%$ respectively, with none of the others (arabinose, mannose, galactose, glucose and sucrose) showing any change in catalytic activity.

\section{Effect of metal ions and chemical compounds on enzyme activity}

The effects of various metal ions and reagents on $\beta$ xylosidase activity were assayed at $10 \mathrm{mM}$ and $20 \mathrm{mM}$ concentrations (Figure 3B). Mosrt notably the addition of $\mathrm{Zn}^{2+}(10 \mathrm{mM})$ enhanced enzyme activity by $80 \%$. The detergent SDS at $20 \mathrm{mM}$ reduced the catalytic activity by $40 \%$.

\section{Discussion}

A $\beta$-xylosidase encoding gene $(x y l A)$ from Aspergillus oryzae KBN616 was expressed in a soluble, active form under control of the constitutive GAP promoter in

Table 1 Kinetic analysis of synthetic and natural substrates determined in $50 \mathrm{mM}$ sodium phosphate buffer (pH 6.0) at $50^{\circ} \mathrm{C}$

\begin{tabular}{|c|c|c|c|c|}
\hline Substrate & $K_{m}(m M)$ & $\mathrm{V}_{\max }\left(\mu \mathrm{mol} \min ^{-1} \mathrm{mg}^{-1}\right)$ & $\mathbf{k}_{\text {cat }}\left(\sec ^{-1}\right)$ & $\mathrm{k}_{\mathrm{cat}} / \mathrm{Km}\left(\mathrm{mM}^{-1} \mathrm{~s}^{-1}\right)$ \\
\hline pNPX & $1 \pm 0.3$ & $250 \pm 0.001$ & 352.7 & 352.7 \\
\hline pNPX + 20 mM Xylose & $2.9 \pm 0.5$ & $250.5 \pm 23$ & 353.4 & 121.9 \\
\hline pNPX + 20 mM Fructose & $0.1 \pm 0.06$ & $14.5 \pm 3$ & 20.6 & 206 \\
\hline Xylobiose $\left(\mathrm{X}_{2}\right)$ & $2.6 \pm 0.3$ & $25.5 \pm 0.1$ & 36.0 & 13.8 \\
\hline Xylotriose $\left(X_{3}\right)$ & $3.07 \pm 0.3$ & $21.3 \pm 0.3$ & 30.1 & 9.7 \\
\hline Xylotetraose $\left(X_{4}\right)$ & $0.62 \pm 0.4$ & $14.5 \pm 0.003$ & 20.5 & 33.1 \\
\hline
\end{tabular}

\pm standard deviation of the means of triplicate data. 

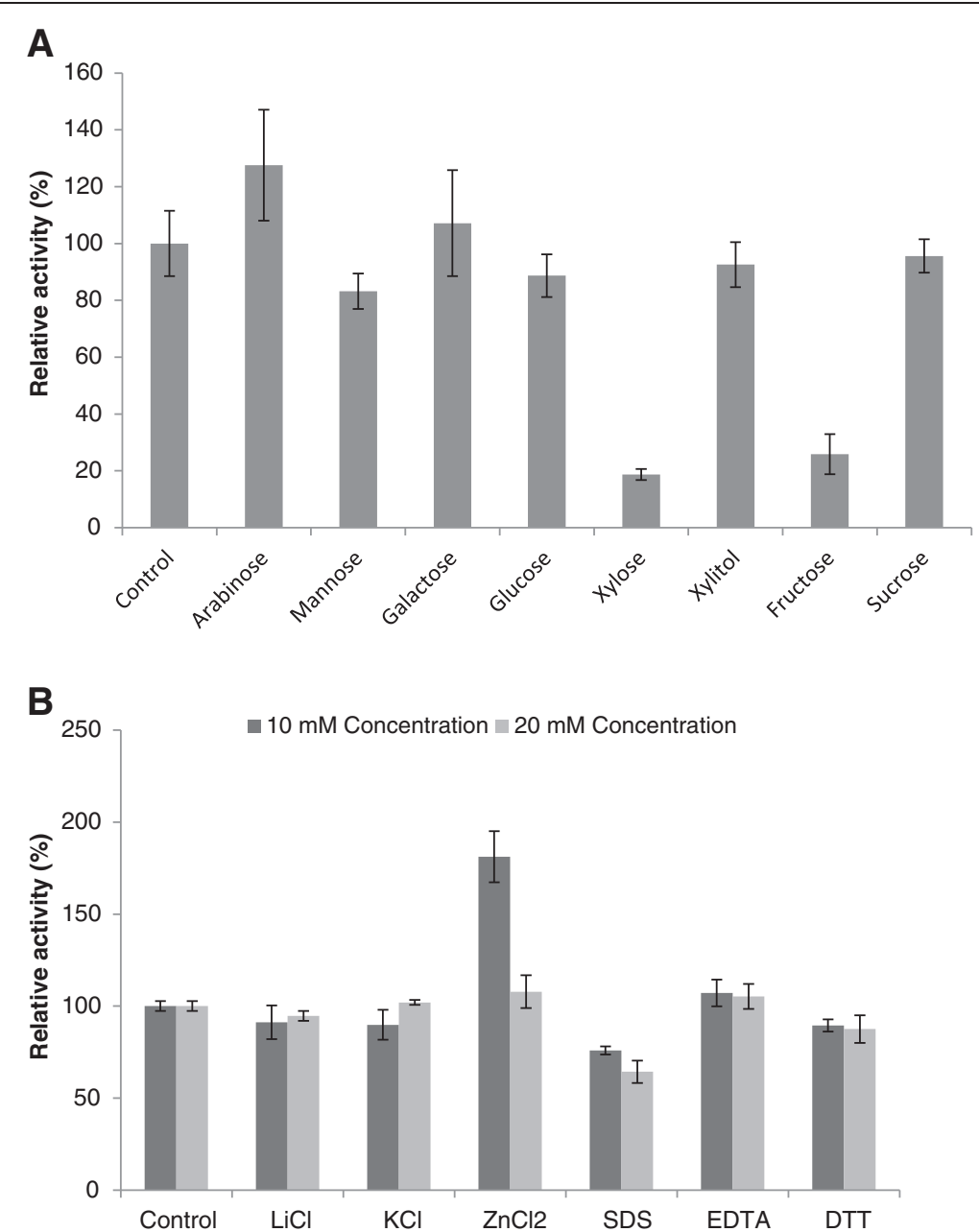

Figure 3 Enzyme activity profiles in the presence of (A) $20 \mathrm{mM}$ carbohydrates and (B) metal ions and chemical compounds within reaction mixtures. All reactions were performed in $50 \mathrm{mM}$ sodium phosphate buffer ( $\mathrm{pH}$ 6.0) and $2 \mathrm{mM} \mathrm{PNPX}$ at $50^{\circ} \mathrm{C}$. Control reaction performed in the absence of carbohydrates and chemicals under identical conditions.

Pichia pastoris. The predicted presence of a native signal sequence (SignalP) was confirmed through secretion of the mature protein by the expression host. XylA was predicted to have a molecular mass of $86.4 \mathrm{kDa}$ and 12 potential N-linked glycosylation sites. Kitamoto et al. (1999) previously identified purified the native enzyme from $A$. oryzae culture supernatant, in which the enzyme produced a single protein band with an apparent molecular mass of $110 \mathrm{kDa}$ on SDS-PAGE. However the molecular mass range of XylA determined by SDS-PAGE from $P$. pastoris was 153 to $165 \mathrm{kDa}$ indicating differences in post-translational modification consistent with the predicted glycosylation sites. Heterologous proteins expressed in $P$. pastoris are subject to glycosylation and several plant cell wall degrading enzymes expressed in $P$. pastoris are reported to be hyper-glycosylated, including $\beta$-xylosidase from Paecilomyces thermophila (Juturu and Wu 2013), cellobiose dehydrogenase from Neurospora crassa (Zhang et al. 2011) and endo-xylanase from Actinomadura sp. S14 (Sriyapai et al. 2011).

The biochemical properties of the recombinant $\beta$-xylosidase closely match the native enzyme with respect to the observed optimal $\mathrm{pH}$ range ( $\mathrm{pH} 4.5-5$ ) and temperature $\left(55^{\circ} \mathrm{C}\right)$ for enzyme activity. These are comparable to other fungal xylosidases (Saha 2003; La Grange et al. 2001; Wakiyama et al. 2008; Zanoelo et al. 2004; Rasmussen et al. 2006), which exhibit optimal activities between $\mathrm{pH} 3-5$ at $60^{\circ} \mathrm{C}$.

The recombinant enzyme was most active against $\mathrm{p}$ nitrophenyl- $\beta$-D-xylopyranoside (PNPX), with minimal activities towards 4-nitrophenyl- $\beta$-D-glucopyranoside (PNPG) and 4-nitrophenyl- $\alpha$-L-arabinofuranoside (PNPAf). Activity towards a broad range of synthetic substrates by other fungal $\beta$-xylosidases has been reported, although maximum activity is generally towards PNPX (MargollesClark et al. 1997; Ohta et al. 2010; Wakiyama et al. 2008; 
Katapodis et al. 2006). The exception to this is Aspergillus awamori X-100 $\beta$-xylosidase, which is reported to exhibit a greater $\mathrm{k}_{\mathrm{cat}}$ against PNPAf (Eneyskaya et al. 2007). The recombinant enzyme exhibited kinetic constants for the hydrolysis of PNPX of $1.0 \mathrm{mM}$ and $353 \mu \mathrm{mol} \mathrm{min}{ }^{-1} \mathrm{mg}^{-1}$ for $\mathrm{K}_{\mathrm{m}}$ and $\mathrm{V}_{\max }$ respectively. A range of kinetic constants have been reported for the hydrolysis of PNPX by fungal $\beta$-xylosidases but these values are similar to those reported for purified $\beta$-xylosidases from Sporotrichum thermophile (Katapodis et al. 2006) and Fusarium proliferatum (Saha 2003). The hydrolysis of various xylooligosaccharides $\left(\mathrm{X}_{2}, \mathrm{X}_{3}\right.$ and $\left.\mathrm{X}_{4}\right)$ was monitored by HPLC. In the presence of individual xylooligosaccharides, xylose was detected as an initial product of catalysis indicating that the recombinant $\beta$-xylosidase is an exo-cutting enzyme. The $\mathrm{k}_{\mathrm{cat}}$ values for the xylooligosaccharides decrease with increasing chain length in the order of $\mathrm{X}_{2}\left(36.0 \mathrm{sec}^{-1}\right)>\mathrm{X}_{3}$ $\left(30.1 \mathrm{sec}^{-1}\right)>\mathrm{X}_{4}\left(20.5 \mathrm{sec}^{-1}\right)$. However, the reduction in the $\mathrm{K}_{\mathrm{m}}$ value for xylotetraose $\left(\mathrm{X}_{4}\right)$ results in a greater catalytic efficiency towards this substrate. The observed changes in the kinetic constants $\left(\mathrm{K}_{\mathrm{m}}\right.$ and $\left.\mathrm{k}_{\mathrm{cat}}\right)$ with respect to xylooligosaccharide chain length show similar patterns to those reported for the $\beta$-xylosidases originating from Talaromyces emersonii, Trichoderma reesei and Aspergillus nidulans (Rasmussen et al. 2006; Dilokpimol et al. 2011). In contrast Neurospora crassa $\beta$-xylosidase is reported to show a reduction in catalytic efficiency towards xylotetraose compared to shorter chain xylooligosaccharides (Kirikyali and Connerton, 2014). This is largely due to a relative reduction in the affinity of the $N$. crassa enzyme towards the xylotetraose substrate ( $>K_{\mathrm{m}}$ value).

Similar to the data reported for the $\beta$-xylosidases from Penicillium sclerotiorum (Knob and Carmona 2009), Talaromyces thermophilus (Guerfali et al. 2009) and Paecilomyces thermophila (Yan et al. 2008) the presence of $20 \mathrm{mM}$ concentrations of the metal ions $\mathrm{Li}^{+}, \mathrm{K}^{+}$or $\mathrm{Zn}^{2+}$ had no effect on enzyme activity. The $\beta$-xylosidase of Talaromyces thermophilus has been reported to retain $44 \%$ activity in the presence of $10 \mathrm{mM}$ of the detergent SDS (Guerfali et al. 2009), and similarly XylA retained catalytic activities of $75 \%$ and $60 \%$ respectively at 10 and $20 \mathrm{mM}$ SDS.

Xylose has been determined to be a competitive inhibitor of recombinant $A$. oryzae $\beta$-xylosidase. In the presence of $20 \mathrm{mM}$ xylose with varying substrate concentrations the $\mathrm{K}_{\mathrm{m}}$ was altered with no corresponding effect on $V_{\max }$. This is consistent with competitive inhibition in which the inhibitor interferes with the catalytic properties of enzyme by affecting substrate binding affinity by conferring a $\mathrm{K}_{\mathrm{i}}$ of $2.7 \mathrm{mM}$. In this respect the recombinant enzyme displays similar characteristic to the $\beta$-xylosidases from A. niger $\left(\mathrm{K}_{\mathrm{i}} 2.9 \mathrm{mM}\right)$ (Gomez et al. 2001) and T. Reesei ( $\left.K_{\mathrm{i}} 2.4 \mathrm{mM}\right)$ (Rasmussen et al. 2006). However, xylose tolerant $\beta$-xylosidases have been reported to exist with $K_{\mathrm{i}}$ values up to $200 \mathrm{mM}$ (Yan et al. 2008; Zanoelo et al. 2004). Fructose has the novel characteristics of an uncompetitive inhibitor in which the inhibitor interacts with the enzyme-substrate complex to prevent product formation. In this case the binding of xylooligosaccharide to the active site of $\beta$-xylosidase creates a binding site for fructose. High substrate concentrations of substrate will increase the occupancy of the active site and the binding sites for fructose, and therefore the effective inhibition. The functional and physiological consequences of this finding should be considered when the enzyme has to function in the presence of mixed substrates.

\section{Competing interests}

JW has become an employee of Biocatalysts Ltd since completion of the project. The authors declare no other competing interests.

\section{Authors' contributions}

NK carried out the biochemical studies and drafted the manuscript. JW carried out the protein expression studies and helped to draft the manuscript. IFC conceived of the study, and participated in its design and coordination and helped to draft the manuscript. All authors read and approved the final manuscript.

\section{Acknowledgements}

This work has been supported by project funds from BBSRC and Biocatalysts Ltd. The authors would like to thank Noriyuki Kitamoto (Aichi Industrial Technology Institute, Japan) for kindly providing the XylA gene. We also would like to thank our technicians, Lorraine Gillet, Nicola Cummings for their advice and David Coles for his assistance with HPLC and Dr Susan Liddell for her assistance with Mass Spectrometry.

Received: 5 July 2014 Accepted: 7 August 2014

Published online: 31 August 2014

\section{References}

Dilokpimol A, Nakai H, Gotfredsen CH, Appeldoorn M, Baumann MJ, Nakai N, Schols HA, Hachem MA, Svensson B (2011) Enzymatic synthesis of $\beta$-xylosyl-oligosaccharides by transylosylation using two $\beta$-xylosidases of glycoside hydrolase family 3 from Aspergillus nidulans FGSC A4. Carbohydr Res 346:421-429

Dyk JSV, Pletschke BI (2012) A review of lignocellulose bioconversion using enzymatic hydrolysis and synergistic cooperation between enzymes - Factors affecting enzymes, conversion and synergy. Biotechnol Adv 30:1458-1480

Eneyskaya EV, Ivanen DR, Bobrov KS, Isaeva-Ivanova LS, Shabalin KA, Savel'ev AN, Golubev AM, Kulminskaya AA (2007) Biochemical and kinetic analysis of the GH 3 family $\beta$-xylosidase from Aspergillus awamori X-100. Arch Biochem Biophys 457:225-234

Gomez M, Isorna P, Rojo M, Estrada P (2001) Chemical mechanism of beta-xylosidase from Trichoderma reesei QM 9414: $\mathrm{pH}$ dependence of kinetic parameters. Biochimie 83:961-967

Guerfali M, Maalej I, Gargouri A, Belghith H (2009) Catalytic properties of the immobilized Talaromyces thermophilus $\beta$-xylosidase and its use for xylose and xylooligosaccharides production. J Mol Cat B 57:242-249

Juturu V, Wu JC (2013) Heterologous expression of $\beta$-xylosidase gene from Paecilomyces thermophila in Pichia pastoris. World J Microbiol Biotechnol 29:249-255

Katapodis P, Nerinckx W, Claeyssens M, Christakopoulos P (2006) Purification and characterization of a thermostable intracellular beta-xylosidase from the thermophilic fungus Sporotrichum thermophile. Pro Biochem 41:2402-2409

Kirikyali N, Connerton IF (2014) Heterologous expression and kinetic characterisation of Neurospora crassa $\beta$-xylosidase in Pichia pastoris. Enzyme Microb Technol 57:63-68

Kitamoto N, Yoshino S, Ohmiya K, Tsukagoshi N (1999) Sequence analysis, overexpression and antisense inhibition of a beta-xylosidase gene, $x y / A$, from Aspergillus oryzae KBN616. Appl Environ Microbiol 65:20-24 
Knob A, Carmona EC (2009) Cell-associated acid $\beta$-xylosidase production by Penicillium sclerotiorum. N Biotechnol 26:60-67

Kulkarni N, Shendye A, Rao M (1999) Molecular and biotechnological aspects of xylanases. FEMS Microbiol Rev 23:411-456

La Grange DC, Pretorius IS, Claeyssens M, ZyI WHV (2001) Degradation of xylan to D-xylose by recombinant Saccharomyces cerevisiae coexpressing the Aspergillus niger $\beta$-xylosidase $(x \mid n D)$ and the Trichoderma reesei xylanase II (xyn2) genes. Appl Environ Microbiol 67:5512-5519

Laemmli UK (1970) Cleavage of structural proteins during the assembly of the head of bacteriophage T4. Nature 227:680-685

Margolles-Clark E, Ihnen M, Penttila M (1997) Expression patterns of ten hemicellulase genes of the filamentous fungus Trichoderma reesei on various carbon sources. J Biotechnol 57:167-179

Michelin M, Polizeli MLTM, Ruzene DS, Silva DP, Vicente AA, Jorge JA, Terenzi HF, Teixeria JA (2012) Xylanase and beta-xylosidase production by Aspergillus ochraceus: New perspectives for the application of wheat straw autohydrolysis liquor. Appl Biochem Biotechnol 166:336-347

Ohta K, Fujimoto H, Fujii S, Wakiyama M (2010) Cell-associated beta-xylosidase from Aureobasidium pullulans ATCC 20524: Purification, properties and characterization of the encoding gene. J Biosci Bioeng 110:152-157

Polizeli MLTM, Rizzatti ACS, Monti R, Terenzi HF, Jorge JA, Amorim DS (2005) Xylanases from fungi: properties and industrial applications. Appl Microbiol Biotechnol 67:577-591

Rasmussen LE, Sorensen HR, Vind J, Vikso-Nielsen A (2006) Mode of action and properties of the $\beta$-xylosidase from Talaromyces emersonii and Trichoderma reesei. Biotechnol Bioeng 94:869-876

Saha BC (2003) Purification and properties of an extracellular beta-xylosidase from a newly isolated Fusarium proliferatum. Bioresour Technol 90:33-38

Sriyapai T, Somyoonsap P, Matsui K, Kawai F, Chansiri K (2011) Cloning of a thermostable xylanase from Actinomadura sp. S14 and its expression in Escherichia coli and Pichia pastoris. J Biosci Bioeng 111:528-536

Teng C, Jia H, Yan Q, Zhou P, Jiang Z (2011) High-level expression of extracellular secretion of a $\beta$-xylosidase gene from Paecilomyces thermophila in Escherichia coli. Bioresour Technol 102:1822-1830

Wakiyama M, Yoshihara K, Hayashi S, Ohta K (2008) Purification and properties of an extracellular $\beta$-xylosidase from Aspergillus japonicus and sequence analysis of the encoding gene. J Biosci Bioeng 106:398-404

Yan QJ, Wang L, Jiang ZQ, Yang SQ, Zhu HF, Li LT (2008) A xylose tolerant $\beta$-xylosidase from Paecilomyces thermophila: Characterisation and its co-action with the endogenous xylanase. Bioresour Technol 99:5402-5410

Zanoelo FF, Polizeli MLTM, Terenzi HF, Jorge JA (2004) Purification and biochemical properties of a thermostable xylose-tolerant $\beta$-xylosidase from Scytalidium thermophilum. J Ind Microbiol Biotechnol 31:170-176

Zhang R, Fan Z, Kasuga T (2011) Expression of cellobiose dehydrogenase from Neurospora crassa in Pichia pastoris and its purification and characterisation. Protein Expr Purif 75:63-69

doi:10.1186/s13568-014-0068-1

Cite this article as: Kirikyali et al:: Characterisation of a recombinant $\beta$-xylosidase (xylA) from Aspergillus oryzae expressed in Pichia pastoris. AMB Express 2014 4:68.

\section{Submit your manuscript to a SpringerOpen ${ }^{\odot}$ journal and benefit from:}

- Convenient online submission

- Rigorous peer review

- Immediate publication on acceptance

- Open access: articles freely available online

- High visibility within the field

- Retaining the copyright to your article

Submit your next manuscript at $\gg$ springeropen.com 